\title{
Structural Diversity in Calmodulin - Peptide Interactions
}

\author{
Zsolt Dürvanger ${ }^{1, *}$ and Veronika Harmat ${ }^{1,2}$
}

\begin{abstract}
${ }^{1}$ Laboratory of Structural Chemistry and Biology, Institute of Chemistry, Eötvös Loránd University, Budapest, Hungary; ${ }^{2}$ MTA-ELTE Protein Modelling Group, Budapest, Hungary
\end{abstract}

\begin{abstract}
Calmodulin $(\mathrm{CaM})$ is a highly conserved eukaryotic $\mathrm{Ca}^{2+}$ sensor protein that is able to bind a large variety of target sequences without a defined consensus sequence. The recognition of this diverse target set allows CaM to take part in the regulation of several vital cell functions. To fully understand the structural basis of the regulation functions of $\mathrm{CaM}$, the investigation of complexes of $\mathrm{CaM}$ and its targets is essential. In this minireview we give an outline of the different types of $\mathrm{CaM}$ - peptide complexes with 3D structure determined, also providing an overview of recently determined structures. We discuss factors defining the orientations of peptides within the complexes, as well as roles of anchoring residues. The emphasis is on complexes where multiple binding modes were found.
\end{abstract}

Keywords: calcium, calmodulin, EF-hands, calmodulin-peptide complexes, protein-peptide interaction, binding motifs

\section{INTRODUCTION}

Calmodulin $(\mathrm{CaM})$ is a 148 residue long calcium-binding protein, that plays a key role in signal transduction pathways of eukaryotic cells. The importance of the protein is reflected by the fact, that its sequence is highly conserved in all eukaryotes and fully conserved in all mammals [1]. The protein consists of two lobes connected by a flexible linker [2]. Each lobe contains two $\mathrm{Ca}^{2+}$ binding EF-hand motifs, the protein is therefore able to bind a total of four $\mathrm{Ca}^{2+}$ ions.

The binding of $\mathrm{Ca}^{2+}$ ions induces large scale conformational changes in the protein which creates the possibility of interacting with targets in a $\mathrm{Ca}^{2+}$-concentration dependent manner. In the absence of $\mathrm{Ca}^{2+}$ ions, the two lobes of CaM adopt a closed or semi-closed conformation, in which the hydrophobic residues of the protein are not accessible to the solvent (Fig. 1a) [3]. This $\mathrm{Ca}^{2+}$-free state of the protein is also called apo form (apo-CaM). Upon $\mathrm{Ca}^{2+}$-binding, the relative angle between the two helices of each EF-hand changes considerably, transforming the two lobes of calmodulin to their open forms. As a result, large hydrophobic surfaces become accessible to the solvent, and therefore also to target proteins of CaM (Fig. 1b) [4]. The conformation of $\mathrm{N}$ - and C-terminal lobes can be closed, open or semi-open, which is usually related to $\mathrm{Ca}^{2+}$ binding by the EFhands. Moreover, the flexible central linker region between the two lobes allows CaM to adopt overall conformations ranging from fully extended to collapsed facilitating binding to peptides of varying sizes. In many of the $\mathrm{Ca}^{2+} / \mathrm{CaM}^{\mathrm{C}}$ complexes, hydrophobic residues of the ligand peptides are anchored in the hydrophobic pockets of CaM.

A large number of biological processes are regulated by CaM, such as smooth muscle contraction [5], gene transcription [6], cell growth and proliferation [7-8], learning and memory [9], protein phosphorylation and dephosphorylation [10]. Target proteins participating in these processes can be modulated by $\mathrm{CaM}$ in a variety of ways. Targets of CaM can be divided into at least six classes based on the mechanism of modulation in the absence and presence of $\mathrm{Ca}^{2+}$ ions [11]. Some proteins bind apo$\mathrm{CaM}$ only, as certain types of myosins, which are responsible for actin-based motility. [12] Other proteins, such as CaM dependent protein kinases are activated by the binding of $\mathrm{Ca}^{2+}$ saturated $\mathrm{CaM}\left(\mathrm{Ca}^{2+} / \mathrm{CaM}\right)[10]$, while other $\mathrm{Ca}^{2+} / \mathrm{CaM} \mathrm{binding}^{2}$ proteins are inactivated upon $\mathrm{CaM}$ binding, such as some G-protein coupled receptor kinases. [13] Some proteins bind both apo-CaM and $\mathrm{Ca}^{2+} / \mathrm{CaM}$ with either similar affinity [14], or with different affinity [15].

\footnotetext{
* Address correspondence to this author at the Laboratory of Structural Chemistry and Biology, Institute of Chemistry, Eötvös Loránd University, Pázmány Péter sétány 1/A,

H-1117, Budapest, Hungary;

E-mail: drvanger@caesar.elte.hu
} 
a)

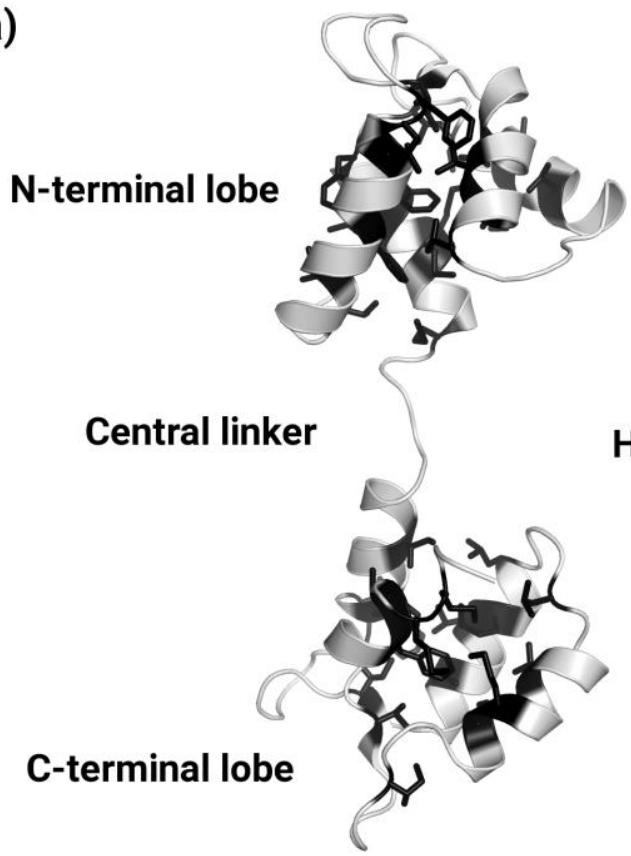

b)

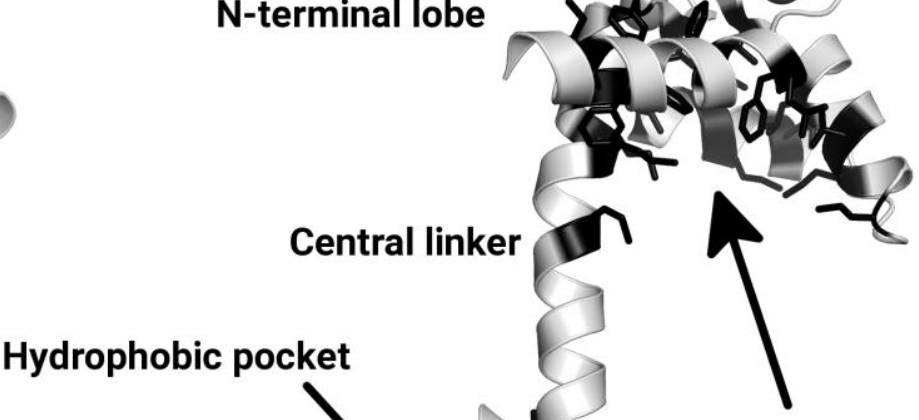

Hydrophobic pocket

Fig. (1). $\mathrm{Ca}^{2+}$ binding of $\mathrm{CaM}$ induces opening of the EF-hand motifs on both lobes and exposing hydrophobic binding surfaces. (a) Structure of apo-CaM with hydrophobic residues (Met, Leu, Ile, Val, Phe) colored in black and side chains shown as sticks (PDB code: 1dmo) [3] (b) Structure of $\mathrm{Ca}^{2+} / \mathrm{CaM}$ with hydrophobic residues colored in black and $\mathrm{Ca}^{2+}$ ions shown with spheres (PDB code: $3 \operatorname{cln}$ ) [4]

$\mathrm{CaM}$ - target protein interactions are often modelled by using peptides of the $\mathrm{CaM}$ - binding region of the partner proteins. It is worth mentioning however, that in some cases the mode of binding can differ between complexes formed with the full-length target protein and those with the binding peptide [16]. CaM recognizes its targets without a defined consensus sequence, but general observations can be made about the usual structure of $\mathrm{CaM}$ binding peptides. CaM target peptides adopt an amphiphilic alpha-helical structure in complexes, usually contain two bulky, hydrophobic anchoring residues, which occupy the hydrophobic pockets of the two lobes of the protein, and often contain a cluster of basic residues before the $\mathrm{N}$-terminal anchor residue [17]

Although the high conservation of the sequence of CaM may suggest that the protein is not a promising drug target, recent literature indicates the possibility of using CaM-antagonists as chemotherapeutic agents [18]. Furthermore, several mutations of $\mathrm{CaM}$ cause severe diseases, such as cardiac arrhythmia [19-21].

The large diversity of $\mathrm{CaM}$ binding regions is related to the flexibility of $\mathrm{CaM}$. The flexible central region between the two lobes allows the protein to adopt significantly different conformations in its complexes with target peptides and proteins. The most common way of classifying CaM binding peptides is based on the distance of the two anchoring residues [22]. In this review we attempt to summarize the present state of our knowledge about the structure of $\mathrm{CaM}$ - target complexes. In a review published in $2013 \mathrm{CaM}$ / peptide structures solved until that time were collected [23]. Here we also summarize the new CaM / peptide structures published after 2013.

Studying the structure and interactions present in $\mathrm{CaM}$ - target complexes is essential to understand the mechanism of disease causing mutations of CaM. Structural studies of CaM - target interactions are complicated by the proteins' ability to form a large variety of complexes even with peptides of highly similar sequences. Due to the flexibility of the protein, it is challenging to predict binding modes based on the sequence of the peptide. [24].

\section{APO-CAM / PEPTIDE COMPLEXES}

$\mathrm{CaM}$ is able to bind to some of its targets in the absence of $\mathrm{Ca}^{2+}$ ions. While $\mathrm{Ca}^{2+} / \mathrm{CaM}$ is able to bind to a large diversity of targets without a consensus sequence, apo-CaM recognizes IQ motifs with the consensus sequence (I/L/V)QxxxRxxx(R/K), 
where $\mathrm{x}$ can be any residue [22]. The importance of CaM - IQ motif interaction is emphasized by the fact, that more, than 100 human proteins contain these CaM binding motifs [12]. Examples of apo-CaM - peptide structures are shown in (Fig. 2).

Myosins are a large family of proteins modulated by the binding of CaM or CaM-like light chains interacting with IQ motifs. While the globular domain of myosins convert chemical energy to mechanical stress upon hydrolysis of ATP, the following IQ motif containing region serves as a mechanical lever. This helical lever arm is stabilized by bound apo-CaM molecules or CaM-like light chains [25, 26] (PDB codes: 2ix7, 5wsv). The first crystal structure of CaM binding a myosin IQ motif was the structure of the first two IQ motifs of myosin V in complex with apo-CaM [25]. This structure revealed that the orientation of the IQ motifs are antiparallel in the complexes that is, the C-terminal lobe of CaM interacts with the $\mathrm{N}$-terminal part of its corresponding IQ motif. In this complex the N-terminal lobe of CaM adopts a closed conformation, the C-terminal lobe however is in a semi open conformation, which is necessary to be able to grip the target peptide.

Several voltage gated ion channels are also modulated by CaM through an IQ motif [27]. The structure of three peptides derived from voltage gated sodium channels is known: NaV1.2 [28] (PDB code: 2m5e), NaV1.5 [29] (PDB code: 2153), NaV1.6 [30] (PDB code: 3wfn). Only the C-terminal lobe of apo-CaM interacts with the peptides in all three complexes. The $\mathrm{C}$-terminal lobe of $\mathrm{CaM}$ is in a semi open conformation in all complexes, while the $\mathrm{N}$-terminal lobe is closed.

Neuromodulin and neurogranin belong to the calpacitin protein family. Their interactions with CaM play a key role in learning and memory formation in neurons [31] (PDB codes: 4e53, 4e50). The structure of the IQ motifs of the two proteins in complex with apo-CaM features $\mathrm{CaM}$ in an extended conformation with a fully helical central linker. The peptides interact with only the C-terminal lobe of the protein in both complexes. Despite the highly similar sequence of the two peptides, they are located in the complexes in an opposite orientation.

Several apo-CaM binding peptides can also bind $\mathrm{Ca}^{2+}$ saturated CaM. Several of the myosins belong to this group of targets. In the case of myosin VIIa, CaM remains bound to the lever arm in the presence of $\mathrm{Ca}^{2+}$ ions, but the binding mode of the protein changes which results in the loss of its stabilizing effect [26] (PDB codes: 5wsv, 5wsu). The IQ motif of the NaV1.2 sodium channel also belong to this group of targets. The binding orientation of the peptide, which interacts only with the Cterminal lobe of $\mathrm{CaM}$, is reversed in response to $\mathrm{Ca}^{2+}$ binding of the protein [32].
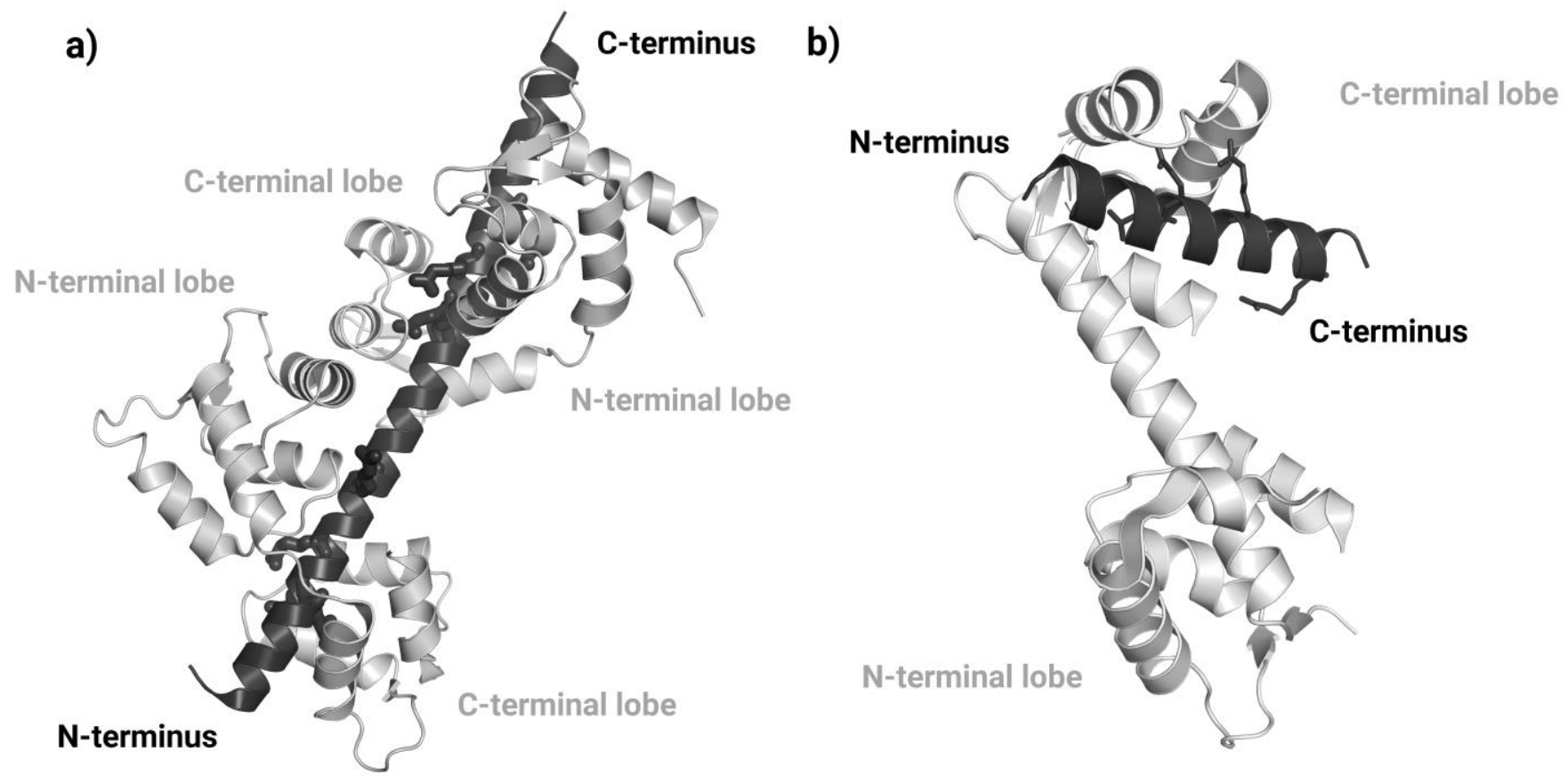

Fig. (2). Examples of apo-CaM - peptide complexes. Calmodulin is shown in light grey, the peptide is in dark grey. Conserved residues of the IQ motifs are shown with sticks (a) The first two IQ motifs of myosin V in complex with apo-CaM (PDB code: 2ix7 [25]) (b) The IQ motif of NaV1.6 sodium channel in complex with apo-CaM (PDB code: 3wfn [30])

\section{CONVENTIONAL $\mathrm{CA}^{2+} / \mathrm{CAM}$ - PEPTIDE COMPLEXES}

In the prototype of $\mathrm{Ca}^{2+} / \mathrm{CaM}$ - peptide complexes a 1:1 complex is formed between the peptide and the protein in which $\mathrm{CaM}$ embraces the peptide, with the anchoring residues buried in its hydrophobic pockets. Typically one hydrophobic side chain of the peptide is accommodated by both hydrophobic pockets of $\mathrm{Ca}^{2+} / \mathrm{CaM}$ [33-34] (PDB codes: 2bbn, 2bbm) These 
complexes can be classified based on the distance between the two anchoring residues of the peptide [22]. Some examples of these complexes are shown in (Fig. 3).

The most common types of complexes are 1-10 and 1-14 complexes, that is where are 8 and 12 residues separate the two anchoring residues, respectively [22]. Beside the anchoring residues at positions 1 and 10/14, often other residues also contribute to the anchoring of the peptides, therefore subgroups of these classes exists based on the position of the other hydrophobic residues, such as the 1-5-10, 1-8-14 and 1-5-8-14 binding motifs [22].

In 1-(5)-10 type $\mathrm{Ca}^{2+} / \mathrm{CaM}$ - peptide complexes there are 8 residues between the two anchoring residues of the peptide. Notable representatives of this class are CaM-dependent protein kinases [35] (PDB code: 1cdl) and voltage gated $\mathrm{Ca}^{2+}$ channels $[36,37]$ (PDB codes: 2f3y, 2f3z; 2be6). Another example of this binding mode is the complex of $\mathrm{Ca}^{2+} / \mathrm{CaM}^{2}$ with a transient receptor potential vanilloid $1 \mathrm{CaM}$ binding peptide [38] (PDB code: 3sui). The most interesting property of this complex is the conformation of the peptide - it forms a short, 10 residue long helical region flanked by two extended sections, different from most of the CaM binding peptides forming a longer helical structure.

The 1-(5)-(8)-14 CaM binding motif is characterized by a distance of 12 residues between the two main anchoring residues. The residues at positions 5 and 8 often also contribute to the anchoring of the peptide. This family includes many well studied CaM targets, such as myosin light chain kinase (MLCK). It is worth mentioning, that the overall conformation of the complex is not fully determined by the CaM binding motif utilized by the peptide, the motifs confer the topology of the complex. The relative orientation of the two lobes of $\mathrm{CaM}$ in the complexes with the binding peptide of endothelial nitric oxide synthase [39] (PDB code: $1 \mathrm{n} 1 \mathrm{w}$ ) and MLCK peptides [40] for instance differs significantly despite having the same 1-(5)-8-14 CaM binding motif. The former complex shows a variability which may be characteristics of other CaM complexes too: the cluster of basic residues of the peptide can establish different interaction pattern with $\mathrm{CaM}$, while the overall conformation and anchoring residues of the peptide are maintained.

In 1-(10)-16 type $\mathrm{Ca}^{2+} / \mathrm{CaM}$ - peptide structures there are 14 residues between the two main anchoring residues. This binding motif can be observed for instance in complexes of $\mathrm{Ca}^{2+} / \mathrm{CaM}$ with the binding peptide from $\mathrm{Ca}^{2+}$-calmodulindependent kinase kinase. [41] (PDB code: 1ckk)

Apart from the previously mentioned classes, $\mathrm{Ca}^{2+} / \mathrm{CaM}$ - peptide complexes are known with different, unusual binding motifs, such as the 1-18 [42] (PDB code: 2kne), 1-17 [43] (PDB code: 2bcx) and 1-11 [44] (PDB code: 3ewt, 3ewv) binding motifs.
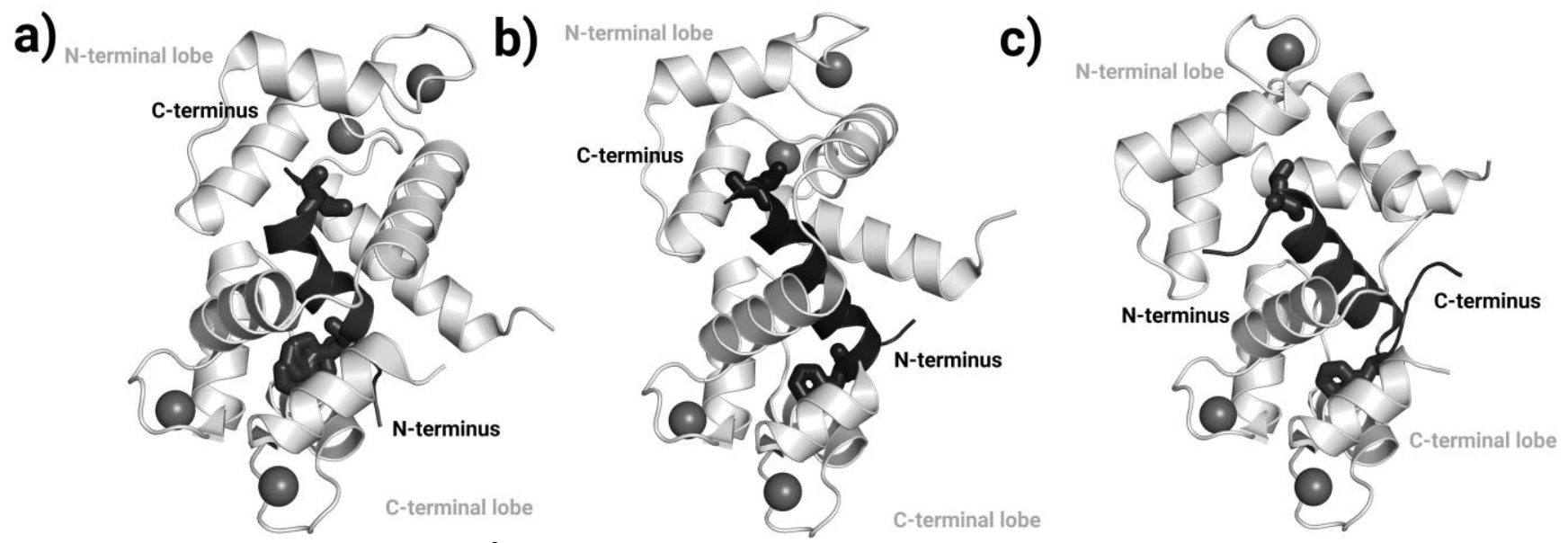

Fig. (3). Examples of conventional $\mathrm{Ca}^{2+} / \mathrm{CaM}$ - peptide complexes. Calmodulin is shown in light grey, the peptides in dark grey and $\mathrm{Ca}^{2+}$ ions with middle grey spheres. The C-terminal lobes of $\mathrm{CaM}$ are in the same orientation. Sticks are shown for the main anchoring residues. (a) An 1-10 type complex of $\mathrm{Ca}^{2+} / \mathrm{CaM}$ with a peptide from the TRPV1 receptor (PDB code: 3sui, [38]) (b) The 1-14 type complex of $\mathrm{Ca}^{2+} / \mathrm{CaM}$ with a peptide from endothelial nitric oxide synthase (PDB code: 1niw, [39]) (c) The 1-16 type complex between $\mathrm{Ca}^{2+} / \mathrm{CaM}$ and a nematode $\mathrm{Ca}^{2+} /$ calmodulin-dependent kinase kinase peptide (PDB code: 1iq5, [45])

\section{UNUSUAL $\mathrm{CA}^{2+} / \mathrm{CAM}$ - PEPTIDE COMPLEXES}

As a consequence of the extreme flexibility of $\mathrm{CaM}$, a large number of complexes exists that cannot be classified into the previously mentioned families. Some examples are shown in (Fig. 4). 
The binding of a target to $\mathrm{CaM}$ can affect the $\mathrm{Ca}^{2+}$-affinity of its EF-hands [46]. This can result in complexes where the protein is not in a $\mathrm{Ca}^{2+}$-saturated form despite the high external $\mathrm{Ca}^{2+}$-concentration. One such target is the $\mathrm{CaM}$ binding region from eukaryotic elongation factor 2 kinase [47] (PDB code: 5j8h). In this complex the peptide binds by an unusual 1-5-8 motif and interacts mainly with the $\mathrm{C}$-terminal lobe of $\mathrm{CaM}$, which is $\mathrm{Ca}^{2+}$-free even in the presence of high $\mathrm{Ca}^{2+}$ concentration. In contrast, the CaM binding site of AKAP79 also interacts mainly with the C-terminal lobe of CaM, in this complex however the C-terminal lobe binds $\mathrm{Ca}^{2+}$ ions, while the $\mathrm{N}$-terminal lobe is in a closed, $\mathrm{Ca}^{2+}$-free conformation [48] (PDB code: 5nin).

The stoichiometry of conventional CaM - peptide complexes is $1: 1$, in some cases however CaM forms complexes of its targets with different stoichiometries. The CaM binding peptide of calcineurin forms a complex with $\mathrm{Ca}^{2+} / \mathrm{CaM}$ with $2: 2$ stoichiometry, in which the two CaM molecules are in extended conformation, and the N-terminal lobe of the first CaM and the C-terminal lobe of the second $\mathrm{CaM}$ forms a binding site similar to that of found in conventional $\mathrm{Ca}^{2+} / \mathrm{CaM}$ - peptide complexes [49-51] (PDB codes: 2f2p, 2f2o, 2r28, 2w73).

In conventional $\mathrm{Ca}^{2+} / \mathrm{CaM}$ - peptide complexes, the protein wraps around the helical peptide. In contrast, in the complex of the human $\mathrm{Na}^{+} / \mathrm{H}^{+}$exchanger NHE1 regulatory region CaM adopts an elongated conformation with an extended, helical central linker, and the two lobes of the protein bind to two separate regions of the target peptide [52] (PDB code: 2ygg). The CaM binding region of the HIV-1 matrix protein also forms a similar complex with calmodulin [53] (PDB code: 2mgu). Similarly, $\mathrm{CaM}$ binds to two binding sites simultaneously in the complex of the inactivation gate (IG) of the NaV1.5 sodium channel [54] (PDB code: 5dbr). However in this case CaM was co-crystallized with peptides containing only one of the binding sites, resulting in a binding mode different from that of the full-length peptide [55-56] (PDB code: 4djc). The observed binding mode in the crystal structure of the full-length peptide containing both binding motifs also differs significantly from that determined using NMR spectroscopy and SAXS [54]. These results clearly show the difficulties that may arise during structural studies of $\mathrm{CaM}$ - peptide interactions.

In the complex of the $\mathrm{CaM}$ binding region of the members the $\mathrm{Kv} 7$ potassium channel family $\mathrm{Ca}^{2+} / \mathrm{CaM}$ binds a bundle of two helices, as shown in (Fig. 4d) [57-59] (PDB codes: 6feg, 6feh; 4v0c, 4umo; 5j03).
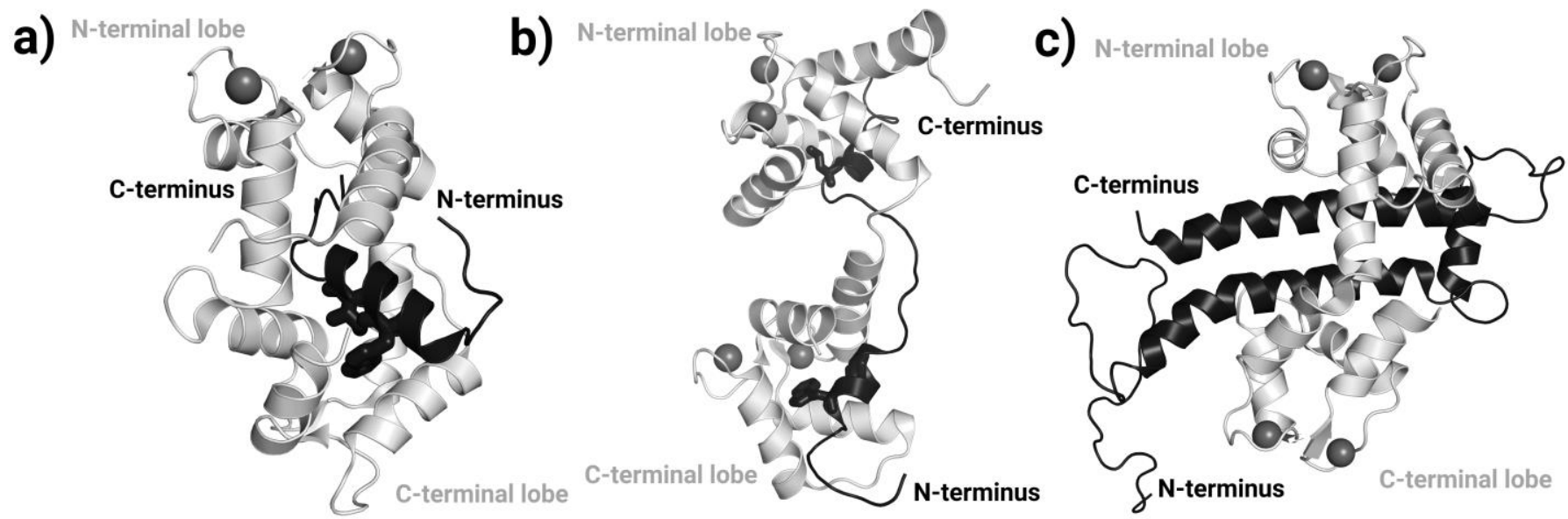

Fig. (4). Examples of unconventional CaM - peptide complexes. Calmodulin is shown in light grey, the peptides in dark grey and $\mathrm{Ca}^{2+}$ ions with middle grey spheres. (a) Structure of $\mathrm{CaM}$ in complex with a peptide from the eukaryotic elongation factor 2 kinase (PDB code: $5 \mathrm{j} 8 \mathrm{~h},[47]$ ), (b) Structure of $\mathrm{Ca}^{2+} / \mathrm{CaM}$ in complex with the $\mathrm{CaM}$ binding region of the HIV-1 myristoylated matrix (MA) protein (PDB code: 2mgu, [53]) Examples shown in a and b, are NMR structures containing an ensemble of complexes possessing the same set of binding interactions but different positions of CaM lobes. One structure of the NMR ensemble is shown. (c) The structure of $\mathrm{Ca}^{2+} / \mathrm{CaM}$ in complex with the hAB segment of the Kv7.2 potassium channel (PDB code: 6feh, [57])

\section{FACTORS INFLUENCING PEPTIDE ORIENTATION IN THE COMPLEXES}

$\mathrm{Ca}^{2+} / \mathrm{CaM}$ - peptide complexes can also be classified based on the orientation of the peptide in the complex. In the majority of $\mathrm{Ca}^{2+} / \mathrm{CaM}$ - peptide complexes the peptide binds in an antiparallel orientation: the C-terminal end of the peptide interacts with the N-terminal hydrophobic pocket of $\mathrm{CaM}$, while the $\mathrm{N}$-terminal end of the peptide interacts with the C-terminal hydrophobic pocket of the protein. Many CaM binding peptides contain a cluster of positively charged residues before the Nterminal anchoring residue (Fig 5a), some peptides however contain this positively charged cluster after the C-terminal anchoring residue. It is a widely accepted proposition that forming most favorable electrostatic interactions is a major force for orientating the peptide: The N-terminal lobe of CaM contains less Asp/Glu residues at the edge of the binding site than the Cterminal lobe, thus the positively charged cluster of the peptide is oriented to bind the latter region. The $\mathrm{N}$-terminal basic cluster 
therefore favors the antiparallel orientation, while the C-terminal basic cluster favors the parallel orientation. [35, 41, 60] (PDB codes: 1cdl; 1ckk; 2lgf) There are exceptions to this proposal however, e.g. the CaM binding helix of the p75NTR receptor contains a cluster of basic residues near the C-terminus of the peptide, while binding to $\mathrm{Ca}^{2+} / \mathrm{CaM}$ in antiparallel orientation [44] (PDB codes: 3ewv, 3ewt). Segment B of the Kv7.4 potassium channel also contains a cluster of basic residues after the Cterminal anchoring residue, but it binds in antiparallel orientation. [24]

The parallel orientation of the peptides (Fig 5b) is observed in only few structures in the PDB database. Peptides corresponding to the CaM binding region of $\mathrm{Ca}^{2+} / \mathrm{CaM}$-dependent kinase kinase (CaMKK) from two different species - rat [41] (PDB code: 1ckk) and the nematode Caenorhabditis elegans [45] (PDB code: 1iq5) - were the first peptides found to bind CaM in parallel orientation. These structures underline the importance of electrostatic interactions in CaM - peptide complexes.

The peptide corresponding to the CaM binding IQ motif of the $\mathrm{CaV} 1.2 \mathrm{Ca}^{2+}$ channel also binds to $\mathrm{Ca}^{2+} / \mathrm{CaM}$ in a parallel orientation. [36] (PDB codes: 2f3y, 2f3z) The most interesting property of this complex is that it could not be classified into any of the $\mathrm{Ca}^{2+} / \mathrm{CaM}$ - peptide complex groups based on the distance between the anchoring residues, because no definite anchoring residues could be identified. This peptide also contains a cluster of basic residues near the C-terminus, but only one of these residues forms interactions with $\mathrm{CaM}$, thus questioning the proposition about the role of the basic cluster. The structure of the complex of $\mathrm{CaM}$ binding a peptide corresponding to a longer section of the $\mathrm{CaM}$ binding region of the $\mathrm{CaV} 1.2 \mathrm{Ca}^{2+}$ channel were also determined. [37] (PDB code: 2be6). The peptide in this structure also binds in a parallel fashion. Interestingly, the asymmetric unit of the crystals contained two complexes, in two different conformations, which differ slightly from the structure with the shorter peptide. Most of the positively charged side chains of the peptide formed salt bridges with $\mathrm{CaM}$, in contrast, those side chains were disordered in the complex of the shorter segment of this CaM binding helix. The differences between the binding modes of the two peptides point to the importance of the optimal selection of the length of the peptides.

Crystal structures of CaM - peptide complexes usually show the peptide in one - presumably the most favored conformation. With other methods however, it is possible to investigate multiple binding modes in complexes. Chemical cross linking combined with mass spectrometry was used successfully to determine the orientation of multiple peptides in complex with $\mathrm{Ca}^{2+} / \mathrm{CaM}$, such as the CaM binding peptide derived from adenylyl cyclase 8 [61], the CaM binding section of Munc13 [62], melittin and mastoparan [63-64]. Interestingly, melittin and mastoparan was shown to prefer the parallel orientation while being able to bind also in antiparallel orientation, despite having the cluster of basic residues after the C-terminal anchoring residue. Results of chemical cross linking experiments combined with MS spectroscopy also suggested that melittin is able to bind to $\mathrm{Ca}^{2+} / \mathrm{CaM}$ in multiple binding modes within the two orientations [64].

NMR spectroscopy is also able to provide information about multiple binding modes in $\mathrm{Ca}^{2+} / \mathrm{CaM}$ - peptide complexes. The $\mathrm{CaM}$ binding peptide from the rat olfactory cyclic nucleotide-gated ion channel was also shown to bind to $\mathrm{Ca}^{2+} / \mathrm{CaM}$ in both orientations. [65] (PDB code: $2 \mathrm{~m} 0 \mathrm{j}, 2 \mathrm{~m} 0 \mathrm{k}$ ). This peptide contains a unique palindromic sequence between the two anchoring residues, which explains its ability to bind to $\mathrm{Ca}^{2+} / \mathrm{CaM}$ in both orientations with similar affinity within the same solution.

The $\mathrm{CaM}$ binding region of calcineurin is another peptide that is able to bind to $\mathrm{Ca}^{2+} / \mathrm{CaM}$ in both orientations. In the crystal structure, the peptide binds in antiparallel orientation [66] (PDB code: 4q5u), while in the NMR structure it binds in parallel orientation [67] (PDB code: 2jzi), despite having no basic cluster at the C-terminus. 

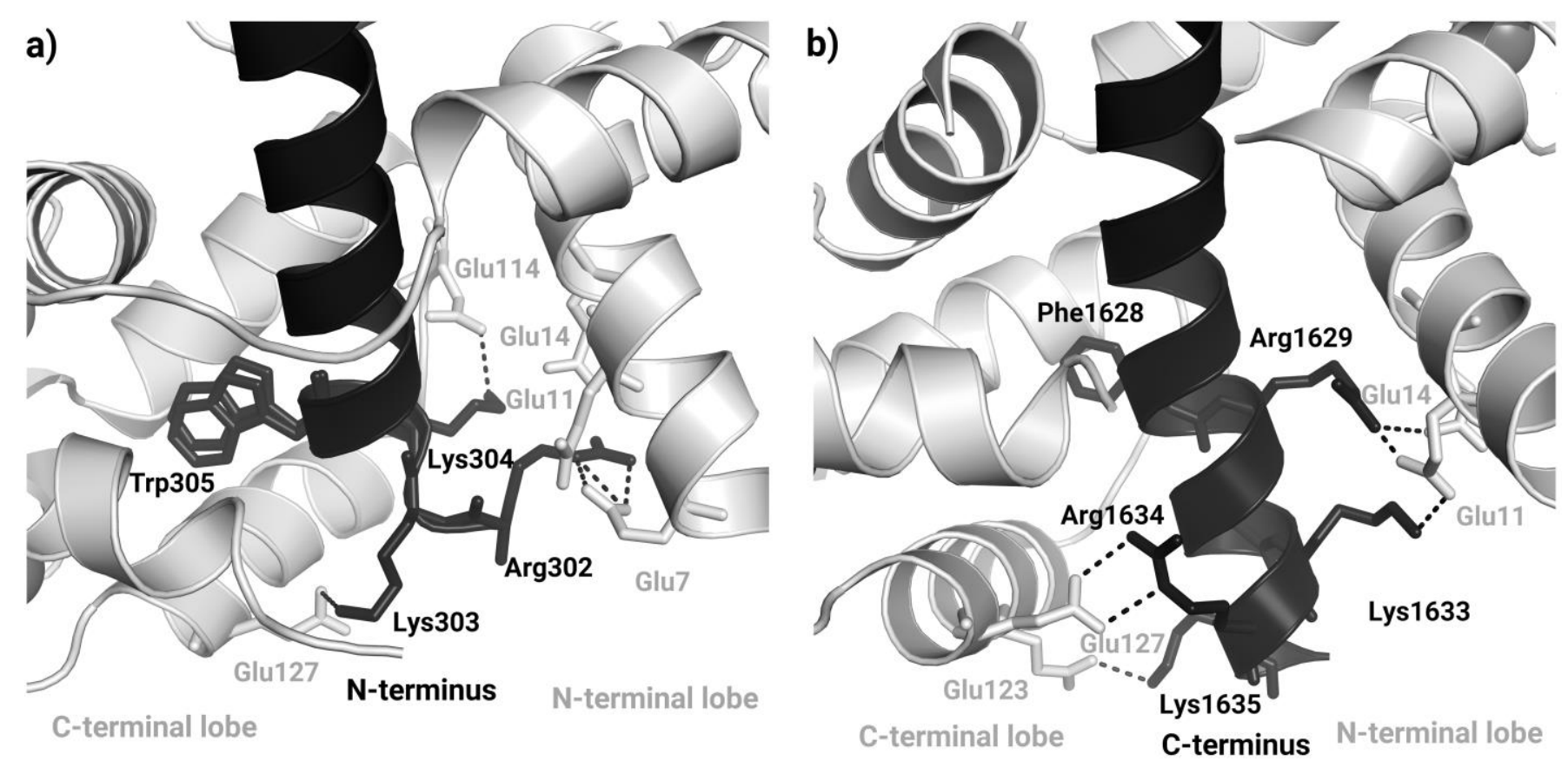

Fig. (5). Interactions of the basic cluster of $\mathrm{CaM}$ binding peptides with $\mathrm{Ca}^{2+} / \mathrm{CaM}$. Calmodulin is shown in light grey, the peptides in dark grey and $\mathrm{Ca}^{2+}$ ions with middle grey spheres. (a) Salt bridges in the complex of $\mathrm{Ca}^{2+} / \mathrm{CaM}$ with a peptide from DAP kinase. (PDB code: 1yr5) The peptide is in the antiparallel orientation. (b) Interactions of the basic cluster in the $\mathrm{Ca}^{2+} / \mathrm{CaM} / \mathrm{CaV} 1.2$ complex, in which the peptide is in the parallel orientation (PDB code: 2be6, [37])

\section{RECENTLY PUBLISHED CAM - PEPTIDE STRUCTURES}

Tidow et al summarized characteristics of the known CaM - peptide complexes. [23] Since then more than 30 new structures were presented, including examples of classical anchoring modes as well as complexes with unusual binding mode of the peptide. Here we compile the PDB accession codes and main properties of these recent $\mathrm{CaM} /$ peptide complex structures (Table 1). Only $\mathrm{Ca}^{2+} / \mathrm{CaM} /$ peptide and apo-CaM / peptide complexes without mutations of $\mathrm{CaM}$ and with both lobes present were analyzed. 
Table 1. Summarizing characteristics of structures of CaM - peptide complexes published in the PDB database after 2013.

\begin{tabular}{|c|c|c|c|c|c|c|c|}
\hline $\begin{array}{l}\text { PDB } \\
\text { code }\end{array}$ & Target & $\begin{array}{l}\text { Number of } \\
\mathrm{Ca}^{2+} \text { ions / } \\
\mathrm{CaM} \\
\text { molecule }\end{array}$ & $\begin{array}{l}\text { Stoichiomet } \\
\text { ry }\end{array}$ & Binding mode & $\begin{array}{l}\text { Peptide } \\
\text { orientation }\end{array}$ & $\begin{array}{l}\text { Location } \\
\text { of basic } \\
\text { cluster }\end{array}$ & $\begin{array}{l}\text { Referenc } \\
\mathrm{e}\end{array}$ \\
\hline \multicolumn{8}{|c|}{ apo-CaM / peptide complexes } \\
\hline $4 \mathrm{e} 53$ & Neuromodulin & 0 & $1: 1$ & $\begin{array}{l}\text { Extended CaM, peptide } \\
\text { bound to C-terminal lobe } \\
\text { only }\end{array}$ & - & - & \multirow{2}{*}[31]{} \\
\hline $4 \mathrm{e} 50$ & Neurogranin & 0 & $1: 1$ & $\begin{array}{l}\text { Extended CaM, peptide } \\
\text { bound to C-terminal lobe } \\
\text { only }\end{array}$ & - & - & \\
\hline $3 w f n$ & NaV1.6 IQ motif & 0 & $1: 1$ & $\begin{array}{l}\text { Extended CaM, peptide } \\
\text { bound to C-terminal lobe } \\
\text { only }\end{array}$ & - & - & {$[30]$} \\
\hline $4 \operatorname{lzx}$ & IQCG & 0 & $1: 1$ & $\begin{array}{l}\text { Wrapping around, N- } \\
\text { lobe closed }\end{array}$ & - & - & [68] \\
\hline $5 w s u$ & $\begin{array}{l}\text { Myosin VIIa IQ5- } \\
\text { SAH }\end{array}$ & 0 & $1: 1$ & $\begin{array}{l}\text { Wrapping around, N- } \\
\text { lobe closed }\end{array}$ & - & - & {$[26]$} \\
\hline $6 b 81$ & $\begin{array}{l}\mathrm{Kv} 7.4 \quad(\mathrm{KCNQ} 4) \\
\mathrm{AB} \text { domain }\end{array}$ & 0 & $1: 1$ & $\begin{array}{l}\text { Wrapping around, two } \\
\text { helices between CaM } \\
\text { lobes }\end{array}$ & - & - & [69] \\
\hline \multicolumn{8}{|c|}{$\mathrm{Ca}^{2+} / \mathrm{CaM} /$ peptide complexes } \\
\hline 4gow & $\begin{array}{l}\text { Kv7.4(KCNQ4) B } \\
\text { helix }\end{array}$ & 4 & $1: 1$ & $1-(10)-14$ & $\begin{array}{l}\text { Antiparalle } \\
1\end{array}$ & C-terminus & {$[24]$} \\
\hline $2 \operatorname{lv} 6$ & $\begin{array}{l}\text { Skeletal muscle } \\
\text { myosin light chain } \\
\text { kinase }\end{array}$ & 4 & $1: 1$ & $1-14$ & $\begin{array}{l}\text { Antiparalle } \\
1\end{array}$ & N-terminus & [70] \\
\hline $2 \mathrm{~m} 0 \mathrm{k}$ & $\begin{array}{l}\text { Rat olfactory } \\
\text { cyclic nucleotide- } \\
\text { gated ion channel }\end{array}$ & 4 & $1: 1$ & $1-14$ & Parallel & N-terminus & \multirow{2}{*}[65]{} \\
\hline $2 \mathrm{~m} 0 \mathrm{j}$ & $\begin{array}{l}\text { Olfactory cyclic } \\
\text { nucleotide-gated } \\
\text { ion channel }\end{array}$ & 4 & $1: 1$ & $1-14$ & $\begin{array}{l}\text { Antiparalle } \\
1\end{array}$ & N-terminus & \\
\hline $2 \mathrm{mgu}$ & $\begin{array}{l}\text { HIV-1 matrix } \\
\text { protein }\end{array}$ & 4 & $1: 1$ & $\begin{array}{l}\text { Extended CaM, two } \\
\text { lobes binding different } \\
\text { regions }\end{array}$ & - & - & {$[53]$} \\
\hline $2 \mathrm{mg} 5$ & $\begin{array}{l}\text { Endothelial } \\
\text { nitrogen } \\
\text { synthase }\end{array}$ & 4 & $1: 1$ & $1-10-14$ & $\begin{array}{l}\text { Antiparalle } \\
1\end{array}$ & - & [71] \\
\hline $4 \mathrm{~m} 11$ & IQCG & 4 & $1: 1$ & $1-10$ & $\begin{array}{l}\text { Antiparalle } \\
1\end{array}$ & - & [68] \\
\hline
\end{tabular}




\begin{tabular}{|c|c|c|c|c|c|c|c|}
\hline $4 q 5 u$ & Calcineurin & 4 & $1: 1$ & $\begin{array}{l}1-7 \text { / anchoring residues } \\
\text { not buried deeply in } \\
\text { hydrophobic pockets }\end{array}$ & $\begin{array}{l}\text { Antiparalle } \\
1\end{array}$ & $\mathrm{~N}$-terminus & [66] \\
\hline $4 \mathrm{v} 0 \mathrm{c}$ & \multirow{2}{*}{$\begin{array}{l}\text { Kv7.1 proximal C- } \\
\text { terminal domain }\end{array}$} & 2 & $2: 2$ & $\begin{array}{l}\text { Both CaM molecules } \\
\text { bind to a two-helix } \\
\text { bundle }\end{array}$ & - & - & \multirow{2}{*}{ [58] } \\
\hline 4umo & & 2 & $2: 2$ & $\begin{array}{l}\text { Both CaM molecules } \\
\text { bind to a two-helix } \\
\text { bundle }\end{array}$ & - & - & \\
\hline 2 mes & $\begin{array}{l}\text { Postsynaptic } \\
\text { density protein-95 }\end{array}$ & 4 & $1: 1$ & $\begin{array}{l}\text { Wrapping around, } \\
\text { unusual binding motif }\end{array}$ & Parallel & $\begin{array}{l}1 \text { Arg at C- } \\
\text { terminus }\end{array}$ & [72] \\
\hline 5dow & $\begin{array}{l}\text { Murine } \mathrm{Cl}^{-} / \mathrm{HCO}_{2}^{-} \\
\text {exchanger } \\
\text { SLC26A3 }\end{array}$ & 4 & $1: 1$ & $1-12$ & $\begin{array}{l}\text { Antiparalle } \\
1\end{array}$ & N-terminus & [73] \\
\hline $5 \mathrm{kbq}$ & STRA6 & 4 & $1: 1$ & $\begin{array}{l}\text { Unusual } \\
\text { conformation }\end{array}$ & $\begin{array}{l}\text { Antiparalle } \\
1\end{array}$ & $\mathrm{~N}$-terminus & [74] \\
\hline $5 \mathrm{j} 8 \mathrm{~h}$ & $\begin{array}{l}\text { Eukaryotic } \\
\text { elongation factor } 2 \\
\text { kinase }\end{array}$ & 2 & $1: 1$ & $1-5-8$ & $\begin{array}{l}\text { Antiparalle } \\
1\end{array}$ & - & [47] \\
\hline $5 \mathrm{j} 03$ & $\begin{array}{l}\text { Chimeric Kv7.2 - } \\
\text { Kv7.3 proximal C- } \\
\text { terminal domain }\end{array}$ & 4 & $1: 1$ & $\begin{array}{l}\text { CaM binds a two-helix } \\
\text { bundle }\end{array}$ & - & - & [59] \\
\hline $5 \mathrm{wsv}$ & Myosin VIIa IQ5 & 4 & $1: 1$ & $1-5-14-18$ & Parallel & $\begin{array}{l}\text { Both } \\
\text { termini }\end{array}$ & [26] \\
\hline $5 \mathrm{dbr}$ & $\begin{array}{ll}\text { Human } & \text { cardiac } \\
\mathrm{Na}+ & \text { channel } \\
\mathrm{NaV} 1.5 & \\
\text { inactivation gate }\end{array}$ & 4 & $1: 1$ & $\begin{array}{l}\text { Extended CaM, peptide } \\
\text { bound to N-terminal lobe } \\
\text { only }\end{array}$ & - & - & [54] \\
\hline $5 \mathrm{t} 0 \mathrm{x}$ & ER alpha peptides & 4 & $1: 2$ & $\begin{array}{l}\text { Unusual CaM } \\
\text { conformation, each lobe } \\
\text { binds 1 peptide }\end{array}$ & - & - & $-*$ \\
\hline $2 \mathrm{n} 8 \mathrm{j}$ & $\begin{array}{l}\text { Endothelial nitric } \\
\text { oxide synthase }\end{array}$ & 2 & $1: 1$ & $\begin{array}{l}\text { Wrapping around, N- } \\
\text { lobe closed }\end{array}$ & $\begin{array}{l}\text { Antiparalle } \\
1\end{array}$ & N-terminus & [75] \\
\hline 5hit & $\begin{array}{l}\text { EAG1 potassium } \\
\text { channel }\end{array}$ & 2 & $1: 1$ & $\begin{array}{l}\text { Extended CaM, peptide } \\
\text { bound to C-terminal lobe } \\
\text { only }\end{array}$ & - & - & [76] \\
\hline $5 \mathrm{jqa}$ & RM20 & 4 & $1: 1$ & $1-14$ & $\begin{array}{l}\text { Antiparalle } \\
1\end{array}$ & $\mathrm{~N}$-terminus & $-*$ \\
\hline $5 \mathrm{j} 7 \mathrm{j}$ & $\begin{array}{l}\text { Postsynaptic } \\
\text { density protein-95 }\end{array}$ & 4 & $1: 1$ & $\begin{array}{l}\text { Wrapping around, } \\
\text { unusual binding motif }\end{array}$ & Parallel & $\begin{array}{l}1 \text { Arg at } \mathrm{C} \text { - } \\
\text { terminus }\end{array}$ & $-*$ \\
\hline $6 \mathrm{bbm}$ & $\begin{array}{l}\text { Kv7.4 (KCNQ4) } \\
\text { AB domain }\end{array}$ & $1-2$ & $1: 1$ & $\begin{array}{l}\text { CaM binds a two-helix } \\
\text { bundle }\end{array}$ & - & - & [69] \\
\hline
\end{tabular}




\begin{tabular}{|c|c|c|c|c|c|c|c|}
\hline 6bbn & & 1 & $1: 1$ & $\begin{array}{l}\text { CaM binds a two-helix } \\
\text { bundle }\end{array}$ & - & - & \\
\hline 6feg & \multirow{2}{*}{$\begin{array}{l}\text { Kv7.2 } \\
\text { domain }\end{array}$} & 2 & $1: 1$ & $\begin{array}{l}\text { CaM binds a two-helix } \\
\text { bundle }\end{array}$ & - & - & \multirow{2}{*}{ [57] } \\
\hline $6 f e h$ & & 4 & $1: 1$ & $\begin{array}{l}\text { CaM binds a two-helix } \\
\text { bundle }\end{array}$ & - & - & \\
\hline 5 nin & AKAP79 & 2 & $1: 1$ & $\begin{array}{l}\text { 1-4-7-8, } \\
\text { anchored to C-terminal } \\
\text { lobe only }\end{array}$ & - & - & [48] \\
\hline
\end{tabular}

* To be published

\section{CONCLUSION}

Since determining the first CaM - target peptide complexes in the early '90s [33, 35] more than 200 structures of CaM complexes were deposited in the Protein Data Bank (PDB [77]) - more than 30 in the last 15 years, in line with the importance of $\mathrm{CaM}$ in a wide range of regulating processes. Based on the early studies some clear rules on structural characteristics of these complexes were established: the target peptide is in helical conformation; anchoring residues are bound in hydrophobic pockets of $\mathrm{Ca}^{2+} / \mathrm{CaM}$; CaM is in a collapsed conformation [34]; a cluster of positively charged residues orient the peptide. However the growing number of exceptions indicate, that plasticity of $\mathrm{CaM}$ and even its targets' binding segments makes it hard to find universal rules or distinct types of complexes. There are at least three levels of flexibility of CaM: flexibility of the central region; modification of the binding surface upon $\mathrm{Ca}^{2+}$ binding, and shape adaptation of the binding region (e.g. hydrophobic pockets) by fine conformational changes of surface residues. Recent structures indicate the importance of careful choice of the length of target peptide: changing the length of the segment of the same target sequence can significantly effect the binding mode. The ability of some peptides to bind to $\mathrm{Ca}^{2+} / \mathrm{CaM}$ in two opposing orientations, and the exceptions to the rule about the basic residues suggest that the position of the basic cluster may not be the only determinant of peptide orientation in $\mathrm{Ca}^{2+} / \mathrm{CaM}$ - peptide complexes. Examples of multiple binding mode of the same peptide detected in the structures or detected using different methods underline the importance of using multiple comparative methods to fully characterize CaM complexes.

\section{ACKNOWLEDGEMENTS}

The research within projects No. VEKOP-2.3.2-16-2017-00014 and VEKOP-2.3.3-15-2017-00018 was supported by the European Union and the State of Hungary, co-financed by the European Regional Development Fund. This work was supported by the Hungarian National Research and Innovation Office under grants 2018-1.2.1-NKP-2018-00005 and Hungarian Scientific Research Fund OTKA K116305, as well as by the MedInProt program of the Hungarian Academy of Sciences.

\section{REFERENCES}

1. Collins, J.H.; Greaser, M.L.; Potter, J.D.; Horn, M.J. Determination of the Amino Acid Sequence of Troponin C from Rabbit Skeletal Muscle. J. Biol. Chem., 1977, 252(18), 6356-6362

2. Barbato, G.; Ikura, M.; Kay, L.E.; Pastor, R.W.; Bax, A. Backbone dynamics of calmodulin studied by 15 N relaxation using inverse detected two-dimensional NMR spectroscopy: the central helix is flexible. Biochemistry, 1992, 31(23), 5269-5278

3. Zhang, M.; Tanaka, T.; Ikura, M. Calcium-induced conformational transition revealed by the solution structure of apocalmodulin. Nat.Struct.Mol.Biol., 1995, 2, 758-767 
4. Babu, Y.S.; Bugg, C.E.; Cook, W.J. Structure of calmodulin refined at 2.2 A resolution. J. Mol. Biol., 1988, 204(1), 191-204

5. Walsh, M.P. Calmodulin and the regulation of smooth muscle contraction. Mol. Cell. Biochem., 1994, 135(1), 21-41

6. Rasmussen, C.D.; Means, A.R. Calmodulin, cell growth and gene expression. Trends Neurosci., 1989, 12(11), 433438

7. Rasmussen, C.D.; Means, A.R. Calmodulin is involved in regulation of cell proliferation. EMBO J., 1987, 6(13), 3961-3968

8. Takuwa, N.; Zhou, W.; Takuwa, Y. Calcium, calmodulin and cell cycle progression. Cell. Signal., 1995, 7(2), 93-104

9. Soderling, T.R. Calcium/calmodulin-dependent protein kinase II: role in learning and memory. Mol. Cell. Biochem., 1993, 127-128, 93-101

10. Swulius, M.T.; Waxham, M.N. Ca(2+)/calmodulin-dependent protein kinases. Cell. Mol. Lie.Sci., 2008, 65(17), 26372657

11. Chin, D.; Means, A.R. Calmodulin: a prototypical calcium sensor. Trends Cell. Biol., 2000, 10(8), 322-328

12. Bähler, M.; Rhoads, A. Calmodulin signaling via the IQ motif. FEBS Lett., 2002, 513, 107-113

13. Iacovelli, L.; Sallese, M.; Mariggiò, S.; de Blasi, A. Regulation of G-protein-coupled receptor kinase subtypes by calcium sensor proteins. FASEB J., 1999, 13(1), 1-8

14. Picton, C.; Klee, C.B.; Cohen, P. The regulation of muscle phosphorylase kinase by calcium ions, calmodulin and troponin-C. Cell. Calcium., 1981, 2(4), 281-294

15. Roth, S.M.; Schneider, D.M.; Strobel, L.A.; VanBerkum, M.F.; Means, A.R.; Wand, A.J. Structure of the smooth muscle myosin light-chain kinase calmodulin-binding domain peptide bound to calmodulin. Biochemistry, 1991, 30(42), 10078-10084

16. Chin, D.; Winkler, K.E.; Means, A.R. Characterization of substrate phosphorylation and use of calmodulin mutants to address implications from the enzyme crystal structure of calmodulin-dependent protein kinase I. J. Biol. Chem., 1997, 272(50), 31235-31240

17. O’Neil, K.T.; DeGrado, W.F. How calmodulin binds its targets: sequence independent recognition of amphiphilic alpha-helices. Trends Biochem. Sci., 1990, 15(2), 59-64

18. Mayur, Y.C.; Jagadeesh, S.; Thimmaiah, K.N. Targeting calmodulin in reversing multi drug resistance in cancer cells. Mini Rev. Med. Chem. 2006, 6(12), 1383-1389

19. Nyegaard, M.; Overgaard, M.T.; Søndergaard, M.T.; Vranas, M.; Behr, E.R.; Hildebrandt, L.L.; Lund, J.; Hedley, P.L.; Camm, A.J.; Wettrell, G.; Fosdal, I.; Christiansen, M.; Børglum, A.D. Mutations in Calmodulin Cause Ventricular Tachycardia and Sudden Cardiac Death. Am. J. Hum. Genet., 2012, 91(4). 703-712

20. Søndergaard, M.T.; Liu, Y.; Larsen, K.T.; Nani, A.; Tian, X.; Holt, C.; Wang, R.; Wimmer, R.; Van Petegem, F.; Fill, M.; Chen, S.R.W; Overgaard, M.T. The Arrhythmogenic Calmodulin p.Phe142Leu Mutation Impairs C-domain Ca2+ Binding but Not Calmodulin-dependent Inhibition of the Cardiac Ryanodine Receptor. J. Biol. Chem., 2017, 292(4), 1385-1395

21. Pipilas, D.C.; Johnson, C.N.; Webster, G.; Schlaepfer, J.; Fellmann, F.; Sekarski, N.; Wren, L.M.; Ogorodnik, K.V.; Chazin, D.M.; Chazin, W.J.; Crotti, L.; Bhuiyan, Z.A.; George, A.L. Jr. Novel calmodulin mutations associated with congenital long QT syndrome affect calcium current in human cardiomyocytes. Heart Rhythm., 2016, 13(10), 20122019

22. Rhoads, A.R.; Friedberg, F. Sequence motifs for calmodulin recognition. FASEB J., 1997, 11(5), 331-340

23. Tidow, H.; Nissen, P. Structural diversity of calmodulin binding to its target sites. FEBS J., 2013, 280(21), 5551-5565

24. Xu, Q.; Chang, A.; Tolia, A.; Minor, D.L. Structure of a Ca(2+)/CaM:Kv7.4 (KCNQ4) B-helix complex provides insight into M current modulation. J. Mol. Biol., 2013, 425(2), 378-394

25. Houdusse, A.; Gaucher, J.F.; Krementsova, E.; Mui, S.; Trybus, K.M.; Cohen, C. Crystal structure of apo-calmodulin bound to the first two IQ motifs of myosin V reveals essential recognition features. PNAS, 2006, 103(51), 1932619331

26. Li, J.; Chen, Y.; Deng, Y.; Unarta, I.C.; Lu, Q.; Huang, X.; Zhang, M. Ca2+-Induced Rigidity Change of the Myosin VIIa IQ Motif-Single a Helix Lever Arm Extension. Structure, 2017, 25(4), 579-591 
27. Mori, M.; Konno, T.; Morii, T.; Nagayama, K.; Imoto, K. Regulatory interaction of sodium channel IQ-motif with calmodulin C-terminal lobe. Biochem. Biophys. Res. Commun., 2003, 307(2), 290-296

28. Feldkamp, M.D.; Yu, L.; Shea, M.A. Structural and Energetic Determinants of Apo Calmodulin Binding to the IQ Motif of the NaV1.2 Voltage-Dependent Sodium Channel. Structure, 2011, 19(5), 733-747

29. Chagot, B.; Chazin, W.J. Solution NMR Structure of apo-calmodulin in complex with the IQ motif of Human Cardiac Sodium Channel NaV1.5. J. Mol. Biol., 2012, 406(1), 106-119

30. Chichili V.P.R.; Xiao, Y.; Seetharaman, J.; Cummins, T.R.; Sivaraman, J. Structural Basis for the Modulation of the Neuronal Voltage-Gated Sodium Channel NaV1.6 by Calmodulin. Sci. Rep., 2013, 3: 2435

31. Kumar V.; Chichili, V.P.R.; Zhong, L.; Tang, X.; Velazquez-Campoy, A.; Sheu, F.S.; Seetharaman, J.; Gerges, N.Z.; Sivaraman, J. Structural Basis for the Interaction of Unstructured Neuron Specific Substrates Neuromodulin and Neurogranin with Calmodulin. Sci. Rep., 2013, 3: 1392

32. Hovey, L.; Fowler, C.A.; Mahling, R.; Lin, Z.; Miller, M.S.; Marx, D.C.; Yoder, J.B.; Kim, E.H.; Tefft, K.M.; Waite, B.C.; Feldkamp, M.D.; Yu, L.; Shea, M.A. Calcium triggers reversal of calmodulin on nested anti-parallel sites in the IQ motif of the neuronal voltage-dependent sodium channel NaV1.2. Biophys. Chem., 2017, 224, 1-19

33. Ikura, M.; Clore, G.M.; Gronenborn, A.M.; Zhu, G.; Klee, C.B.; Bax. A. Solution structure of a calmodulin-target peptide complex by multidimensional NMR. Science, 1992, 256(5057), 632-638

34. Clore, G.M.; Bax, A.; Ikura, M.; Gronenborn, A.M. Structure of calmodulin-target peptide complexes. Curr. Opin. Struct. Biol., 1993, 3, 838-845

35. Meador, W.E.; Means, A.R.; Quiocho F.A. Target enzyme recognition by calmodulin: $2.4 \AA$ structure of a calmodulinpeptide complex. Science, 1992, 257(5074), 1251-1255

36. Fallon, J.L.; Halling, D.B.; Hamilton, S.L.; Quiocho, F.A. Structure of calmodulin bound to the hydrophobic IQ domain of the cardiac $\mathrm{Ca}(\mathrm{v}) 1.2$ calcium channel. Structure, 2005, 13(12), 1881-1886

37. Van Petegem, F.; Chatelain, F.C.; Minor, D.L. Jr. Insights into voltage-gated calcium channel regulation from the structure of the CaV1.2 IQ domain-Ca2+/calmodulin complex. Nat. Struct. Mol. Biol., 2005, 12(12), 1108-1115

38. Lau, S.Y.; Procko, E.; Gaudet, R. Distinct properties of Ca2+-calmodulin binding to N- and C-terminal regulatory regions of the TRPV1 channel. J. Gen. Physiol., 2012, 140(5), 541-555

39. Aoyagi, M.; Arvai, A.S.; Tainer, J.A.; Getzoff, E.D.; Structural basis for endothelial nitric oxide synthase binding to calmodulin. EMBO J., 2003, 22(5). 766-775

40. Ikura, M.; Barbato, G.; Klee, C.B.; Bax, A. Solution structure of calmodulin and its complex with a myosin light chain kinase fragment. Cell. Calcium., 1992, 13(6-7), 391-400, 35

41. Osawa, M.; Tokumitsu, H.; Swindells, M.B.; Kurihara, H.; Orita, M.; Shibanuma, T.; Furuya, T.; Ikura, M. A novel target recognition revealed by calmodulin in complex with Ca2+-calmodulin-dependent kinase kinase. Nat. Struct. Biol., 1998, 6(9), 819-824

42. Juranic, N.; Atanasova, E.; Filoteo, A.G.; Macura, S.; Prendergast, F.G.; Penniston, J.T.; Strehler, E.E. Calmodulin Wraps around Its Binding Domain in the Plasma Membrane Ca2+ Pump Anchored by a Novel 18-1 Motif. J. Biol. Chem., 2010, 285(6), 4015-4024

43. Maximciuc, A.A.; Putkey, J.A.; Shamoo, Y.; Mackenzie, K.R. Complex of calmodulin with a ryanodine receptor target reveals a novel, flexible binding mode. Structure, 2006, 14(10), 1547-1556

44. Cao, P.; Zhang, W.; Gui, W.; Dong, Y.; Jiang, T.; Gong, Y. Structural insights into the mechanism of calmodulin binding to death receptors. Acta. Cryst. D, 2014, 70(6), 1604-1613

45. Kurokawa, H.; Osawa, M.; Kurihara, H.; Katayama, N.; Tokumitsu, H.; Swindells, M.B.; Kainosho, M.; Ikura, M. Target-induced conformational adaptation of calmodulin revealed by the crystal structure of a complex with nematode $\mathrm{Ca}(2+) /$ calmodulin-dependent kinase kinase peptide. J. Mol. Biol., 2001, 312(1), 59-68

46. Bayley, P.M.; Findlay, W.A.; Martin, S.R. Target recognition by calmodulin: dissecting the kinetics and affinity of interaction using short peptide sequences. Protein Sci., 1996, 5(7), 1215-1228

47. Lee, K.; Alphonse, S.; Piserchio, A.; Tavares, C.D.J.; Giles, D.H.; Wellmann, R.M.; Dalby, K.N.; Ghose, R. Structural Basis for the Recognition of Eukaryotic Elongation Factor 2 Kinase by Calmodulin. Structure, 2016, 24(9), 1441-1451

48. Patel, N.; Stengel, F.; Aebersold, R.; Gold, M.G. Molecular basis of AKAP79 regulation by calmodulin. Nat. Commun., 2017, 8(1), 1681 
49. Ye, Q.; Li, X.; Wong, A.; Wei, Q.; Jia, Z. Structure of calmodulin bound to a calcineurin peptide: a new way of making an old binding mode. Biochemistry, 2006, 45(3), 738-745

50. Ye, Q.; Wang, H.; Zheng, J.; Wei, Q.; JIa, Z. The complex structure of calmodulin bound to a calcineurin peptide. Proteins, 2008, 73(1), 19-27

51. Majava, V.; Kursula, P. Domain swapping and different oligomeric States for the complex between calmodulin and the calmodulin-binding domain of calcineurin a. PLoS One, 2009, 4(4), e5402

52. Köster, S.; Pavkov-Keller, T.; Kühlbrandt, W.; Yildiz, Ö. Structure of human Na+/H+ exchanger NHE1 regulatory region in complex with calmodulin and Ca2+. J. Biol. Chem., 2011, 286(47), 40954-40961

53. Vlach, J.; Samal, A.B.; Saad, J.S. Solution structure of calmodulin bound to the binding domain of the HIV-1 matrix protein. J. Biol. Chem., 2014, 289(12), 8697-8705

54. Johnson, C.N.; Potet, F.; Thompson, M.K.; Knollmann, B.C.; George, A.L. Jr.; Chazin, W.J. A Mechanism of Calmodulin Modulation of the Human Cardiac Sodium Channel. Structure, 2018, 26(5), 683-694

55. Sarhan, M.F.; Tung, C.C.; Van Petegem, F.; Ahem, C.A. Crystallographic basis for calcium regulation of sodium channels. PNAS, 2012, 109(9), 3558-3563

56. Potet, F.; Chagot, B.; Anghelescu, M.; Viswanathan P.C.; Stepanovic S.Z.; Kupershmidt, S.; Chazin, W.J.; Balser, J.R. Functional Interactions between Distinct Sodium Channel Cytoplasmic Domains through the Action of Calmodulin. $J$. Biol. Chem., 2009, 284(13), 8846-8854

57. Bernardo-Seisdedos, G.; Nuñez, E.; Gomis-Perez, C.; Malo, C.; Villarroel, Á.; Millet, O. Structural basis and energy landscape for the Ca2+ gating and calmodulation of the Kv7.2 K+ channel. PNAS, 2018, 115(10), 2395-2400

58. Sachyani D.; Dvir M.; Strulovich, R.; Tria, G.; Tobelaim, W.; Peretz, A.; Pongs, O.; Svergun, D.; Attali, B.; Hirsch, J.A. Structural basis of a Kv7.1 potassium channel gating module: studies of the intracellular c-terminal domain in complex with calmodulin. Structure, 2014, 22(11), 1582-1594

59. Strulovich, R.; Tobelaim, W.S.; Attali, B.; Hirsch, J.A. Structural Insights into the M-Channel Proximal CTerminus/Calmodulin Complex. Biochemistry, 2016, 55(38), 5353-5365

60. Gifford, J.L.; Ishida, H.; Vogel, H.J. Structural insights into calmodulin-regulated L-selectin ectodomain shedding. J. Biol. Chem., 2012, 287(32), 26513-26527

61. Schmidt A.; Kalkhof, S.; Ihling, C.; Cooper, D.M.; Sinz, A. Mapping protein interfaces by chemical cross-linking and Fourier transform ion cyclotron resonance mass spectrometry: application to a calmodulin / adenylyl cyclase 8 peptide complex. Eur. J. Mass. Spectrom., 2005, 11(5), 525-534

62. Dimova, K.; Kalkhof, S.; Pottratz, I.; Ihling, C.; Rodriguez-Castaneda, F.; Liepold, T.; Griesinger, C.; Brose, N.; Sinz, A.; Jahn, O. Structural insights into the calmodulin-Munc13 interaction obtained by cross-linking and mass spectrometry. Biochemistry, 2009, 48(25), 5908-5921

63. Chavez, J.D.; Liu, N.L.; Bruce, J.E. Quantification of Protein-Protein Interactions with Chemical Cross-Linking and Mass Spectrometry. J. Proteome. Res., 2011, 10(4), 1528-1537

64. Schulz, D.M.; Ihling, C.; Clore, G.M.; Sinz, A. Mapping the topology and determination of a low-resolution threedimensional structure of the calmodulin-melittin complex by chemical cross-linking and high-resolution FTICRMS: direct demonstration of multiple binding modes. Biochemistry, 2004, 43(16), 4703-4715

65. Irene, D.; Huang, J.W.; Chung, T.Y.; Li, F.Y.; Tzen, J.T.; Lin, T.H.; Chyan, C-L. Binding orientation and specificity of calmodulin to rat olfactory cyclic nucleotide-gated ion channel. J. Biomol. Struct. Dyn., 2013, 31(4), 414-425

66. Dunlap, T.B.; Guo, H.F.; Cook, E.C.; Holbrook, E.; Rumi-Masante, J.; Lester, T.E.; Colbert, C.L.; Vander Kooi, C.W.; Creamer, T.P. Stoichiometry of the calcineurin regulatory domain-calmodulin complex. Biochemistry, 2014, 53(36), 5779-5790

67. Chyan, C-L.; Irene, D.; Lin, S-M. The Recognition of Calmodulin to the Target Sequence of Calcineurin-A Novel Binding Mode. Molecules, 2017, 22(10), e1584

68. Chen, L.T.; Liang, W.X.; Chen, S.; Li, R.K.; Tan, J.L; Xu, P.F.; Luo, L.F.; Wang, L.; Yu, S.H.; Meng, G.; Li, K.K.; Liu, T.X.; Chen, Z.; Chen, S.J. Functional and molecular features of the calmodulin-interacting protein IQCG required for haematopoiesis in zebrafish. Nat. Commun., 2014, 5, 3811

69. Chang, A.; Abderemane-Ali, F.; Hura, G.L.; Rossen, N.D.; Gate, R.E.; Minor. D.L. Jr. A Calmodulin C-Lobe Ca2+Dependent Switch Governs Kv7 Channel Function. Neuron., 2018, 97(4), 836-852 
70. Grishaev, A.; Anthis, N.J.; Clore, G.M. Contrast-Matched Small-Angle X-ray Scattering from a Heavy-Atom-Labeled Protein in Structure Determination: Application to a Lead-Substituted Calmodulin-Peptide Complex. J. Am. Chem. Soc., 2012, 134(36), 14686-14689

71. Piazza, M.; Taiakina, V.; Guillemette S.R.; Guillemette J.G.; Dieckmann T. Solution structure of calmodulin bound to the target peptide of endothelial nitric oxide synthase phosphorylated at Thr495. Biochemistry, 2014, 53(8), 1241-1249

72. Zhang, Y.; Matt, L; Patriarchi, T.; Malik, Z.A.; Chowdhury, D.; Park, D.K.; Renieri, A.; Ames, J.B.; Hell, J.W. Capping of the N-terminus of PSD-95 by calmodulin triggers its postsynaptic release. EMBO J., 2014, 33(12), 13411353

73. Keller, J.P. Solution of the structure of a calmodulin-peptide complex in a novel configuration from a variably twinned data set. 2017, Acta Cryst. D., 73, 22-31

74. Chen, Y.; Clarke, O.B.; Kim, J.; Stowe, S.; Kim, Y.K.; Assur, Z.; Cavalier, M.; Godoy-Ruiz, R.; von Alpen, D.C.; Manzini, C.; Blaner, W.S.; Frank, J.; Quadro, L.; Weber, D.J.; Shapiro, L.; Hendrickson, W.A.; Mancia, F. Structure of the STRA6 receptor for retinol uptake. Science, 2016, 353(6302), aad8266

75. Piazza, M.; Dieckmann, T.; Guillemette, J.G. Structural Studies of a Complex Between Endothelial Nitric Oxide Synthase and Calmodulin at Physiological Calcium Concentration. Biochemistry, 2016, 55(42), 5962-5971

76. Marques-Carvalho, M.J.; Oppermann, J.; Munoz, E.; Fernandes, A.S.; Gabant, G.; Cadene, M.; Heinemann, S.H.; Schonherr, R.; Morais-Cabral, J.H. Molecular Insights into the Mechanism of Calmodulin Inhibition of the EAG1 Potassium Channel. Structure, 2016, 24(10), 1742-1754

77. Berman, H.M.; Westbrook, J.; Feng, Z.; Gilliland, G.; Bhat, T.N.; Weissig, H.; Shindyalov, I.N.; Bourne, P.E. The Protein Data Bank. Nucleic Acids Res., 2000, 28(1), 235-242 